\title{
Farm Production Diversification and Dietary Diversity among Subsistence Farming Households: Panel Data Evidence from South Africa
}

\author{
Sikhulumile Sinyolo ${ }^{1, *(\mathbb{D}}$, Conrad Murendo $\left.{ }^{2}{ }^{(}\right)$, Admire Mutsa Nyamwanza ${ }^{3}\left(\mathbb{O}\right.$, Sithembile Amanda Sinyolo ${ }^{4}$, \\ Catherine Ndinda ${ }^{3}$ (D) and Chijioke Osinachi Nwosu ${ }^{3,5}$ (D)
}

check for

updates

Citation: Sinyolo, S.; Murendo, C.; Nyamwanza, A.M.; Sinyolo, S.A.;

Ndinda, C.; Nwosu, C.O. Farm

Production Diversification and

Dietary Diversity among Subsistence

Farming Households: Panel Data

Evidence from South Africa.

Sustainability 2021, 13, 10325.

https://doi.org/10.3390/

su131810325

Academic Editor: Riccardo Testa

Received: 18 August 2021

Accepted: 7 September 2021

Published: 15 September 2021

Publisher's Note: MDPI stays neutral with regard to jurisdictional claims in published maps and institutional affiliations.

Copyright: (c) 2021 by the authors. Licensee MDPI, Basel, Switzerland. This article is an open access article distributed under the terms and conditions of the Creative Commons Attribution (CC BY) license (https:/ / creativecommons.org/licenses/by/ $4.0 /)$.
1 Human Sciences Research Council, Pretoria 0002, South Africa

CARE International, Mutare 0263, Zimbabwe; cmurendo@gmail.com

3 Human Sciences Research Council, Cape Town 8001, South Africa; anyamwanza@hsrc.ac.za (A.M.N.); Cndinda@hsrc.ac.za (C.N.); cnwosu@hsrc.ac.za (C.O.N.)

4 Agriculture Sector Education and Training Authority, Pretoria 0002, South Africa; sithembile@agriseta.co.za

5 Department of Economics and Finance, University of the Free State, Bloemfontein 9301, South Africa

* Correspondence: SSinyolo@hsrc.ac.za; Tel.: +27-834-658-590

\begin{abstract}
Improving the production of a variety of foods by subsistence farmers has been identified as a key strategy for improving dietary diversity. However, there is limited evidence in South Africa on how one's own production is linked to dietary diversity. This study relies on nationally representative panel data to investigate the extent to which farm production diversity is correlated with dietary diversity. The data indicated a moderate level of household dietary diversity that has been on a declining trend between 2008 and 2017. The farm households produced three food groups (meat, cereals, and vegetables), suggesting more reliance on food purchases than own production. The study found a positive relationship between own production diversification and dietary diversity and that dietary diversity varied by demographics and socio-economic characteristics of households. However, production diversity was not significantly associated with the consumption of micronutrient-rich foods such as fruits or vegetables. Higher levels of education, income per capita, food expenditure, and geographic location were some of the key drivers of dietary diversity among subsistence households. The findings suggest that encouraging subsistence farming households to produce various crop and animal species can be an effective strategy to improve dietary diversity among poor households in South Africa.
\end{abstract}

Keywords: dietary diversity; farm production diversity; subsistence farming; panel data; South Africa

\section{Introduction}

South Africa, as with many countries in the developing world, faces significant food and nutrition challenges, which include persistent hunger, malnutrition, obesity, and non-communicable diseases [1-4]. On the one hand, the country faces undernutrition in young children, and on the other, there is a rising level of obesity in older children and adults. South Africa is comparable to poor countries when it comes to undernutrition and is comparable to richer countries when it comes to overweight challenges [5]. For example, in 2020, 23\% of children under 5 years were stunted in South Africa, a figure higher than the world average (22\%) and significantly higher than the $11 \%$ average of other upper-middle-income economies [5]. On the other hand, the country experienced a $28 \%$ prevalence of obesity among the adult population in 2016, a figure more than two times the average for the global (13\%) or African economies [5].

There is a spatial dimension to undernutrition in South Africa, as most of the undernourished population live in rural areas [6]. These health concerns reflect and are rooted in South Africa's triple challenges of high unemployment, crippling poverty, and deep-rooted inequality, which continue to have implications for access to food and nutritional balance 
for many people. Most low-income households are restricted to a few food options consisting predominantly of starchy staples such as maize and bread, with limited consumption of fruits and vegetables [3,7]. Previous studies have also attributed these health challenges to South Africa's increasingly industrialized and concentrated food system and the expansion of supermarkets which have led to the availability of and easy access to cheap, highly processed foods in both rural and urban areas [8,9]. While these modern food chains are considered efficient, the challenge is in ensuring access to food by the people, especially those located in rural areas, who practice subsistence farming [10]. The social protection system, one of the biggest in the world, while reducing the levels of poverty and food insecurity, is not adequate [11]. Interventions targeting economic growth and income increases are important but do not sufficiently reduce the prevalence of undernutrition [12]. Additionally, Pereira et al. [7] found that while purchasing food instead of own production was important in ensuring food security among the poor located in rural areas of South Africa, their inadequate access to income was a major constraint, and that the poor who did not grow their own fresh produce experienced challenges in accessing micronutrients.

The double burden of malnutrition and poor diets requires South Africa to design strategies for dealing with undernutrition for one section of the population, on the one hand, while also designing options of addressing over-nutrition for another cohort of the population. Numerous strategies have been (and continue to be) implemented to address these challenges. These include agricultural programs, such as the promotion of vegetable gardens (at household or community levels), biofortification (i.e., manipulating crop genes to increase the concentration of target nutrients in staple food crops), promotion of underutilized crops that are nutrient-dense; social services, such as the provision of social grants; nutrition programs, such as school feeding schemes, and nutrition education and counseling; free health services particularly for children under 5 years; and public works programs to enhance income opportunities for poor households [13-15].

Existing evidence suggests that promoting farm production diversification can be an effective strategy for improved dietary quality, nutrition, and micronutrient adequacy $[16,17]$. The production of a diverse range of food crops and items with high nutrient densities at the farm level has long been recognized as a potential pathway to improved dietary diversity and nutrition for farming households [12,18-20]. The Sustainable Development Goals (SDGs) recognize the potential role of agriculture in improving nutrition, with SDG 2 prioritizing the improvement of productivity of small-scale food producers [21,22]. There are several primary pathways through which better household nutrition can be achieved with respect to farm production diversity [22-24]. The first one is that food production diversity ensures the direct availability of a variety of food items for household consumption, which subsequently improves diet quality and nutrition [22,24]. The second pathway is that it ensures increased and stable food options by minimizing production output risks due to shocks such as extreme weather and climate events. Thirdly, producing a diverse range of commodities can lead to increased and stable incomes that households can use to buy diverse food items in times of price volatility, thereby minimizing market risks [24].

Whilst a clear conceptual link can therefore be established between farm production diversity and improved dietary diversity, empirical research findings to support this link in Africa have been inconclusive, with various studies in different contexts reaching different conclusions [12,18,24-26]. An examination of literature by Powell et al. [27], a recent critical review by Jones [17], and a meta-analysis by Sibhatu and Qaim [16] discuss these mixed results. For example, Powell et al. [27] found that six out of the eight studies reviewed reported a positive relationship between farm production diversity and dietary diversity. Meanwhile, Jones [17] found that 95\% (i.e., 19 of the 21) of the reviewed studies reported a positive relationship between farm production diversification and nutrition; a closer look by Sibhatu and Qaim [16] on these studies concluded that many of those studies that found positive correlations also included estimates that were either insignificant or negative for some regions or indicators used. A meta-analysis of 45 studies by Sibhatu and Qaim [16] found that few studies (less than 20\%) reported significant and consistently 
positive linkages between farm production diversity and dietary diversity. According to Sibhatu and Qaim [16], the results differ in specific conditions, with little evidence that increasing farm production diversity can improve dietary diversity and nutrition in most or all situations.

The role of diversified farm production in dietary diversity among subsistence agricultural communities has not been rigorously investigated in South Africa. For example, none of the studies that were reviewed by Powell [27], Jones [17], or Sibhatu and Qaim [16] focused on South Africa. A firm empirical basis for establishing the farm production diversity and improved dietary diversity link is very thin in South Africa [6]. While there are some old studies (e.g., [28]) that attempted to establish the link based on cross-sectional data, these failed to establish an explicit link between food production diversity and improved nutrition among households. Newer studies (e.g., [15]), though providing evidence of a stronger positive correlation, have often been based on unrepresentative small samples with a narrow geographical focus [6]. Few of the studies in the literature linking farm production and dietary diversity or nutrition indicators have relied on panel data (e.g., [18,23,29-32]), with most relying on cross-sectional data (see [16,33-35]). The studies using panel data have often relied on data with mostly two (e.g., [29]) or at most three periods (e.g., [18]).

This paper uses representative longitudinal data with five periods to investigate the role of farm production diversity in dietary diversity in South Africa. Few analyses on this topic, relying on such a wide evidence base, have been conducted in South Africa. While evidence from other developing countries is relevant, it might not be applicable to South Africa given its unique characteristics (e.g., the duality of the farm sector, highly industrialized and concentrated modern food chains, elaborate social protection system, etc.). The following research questions were addressed in this study:

- To what extent does farm production diversification lead to dietary diversity among subsistence households in South Africa?

- What role is played by food purchases in dietary diversity? How does this relate to one's own production diversification in improving dietary diversification?

\section{Materials and Methods}

\subsection{Data}

The five waves of the National Income Dynamics Study (NIDS) data were analyzed in this study. NIDS is a household panel survey, which is nationally representative, implemented by the Southern Africa Labour and Development Research Unit of the University of Cape Town. It is an initiative of South Africa's Department of Planning, Monitoring and Evaluation aimed at tracking and understanding different dimensions of poverty. NIDS examines the livelihoods of individuals and households over time across several themes, such as poverty, labor market participation, household dynamics, migration, economic activities, education achievements, etc. [36]. The sampling design was a two-stage stratified cluster sampling (see Nwosu and Woolard [37] for details).

The first wave of the survey was conducted in 2008 and included a nationally representative sample of over 28,000 individuals in 7300 households across the country (Table 1). The survey has been repeated with the same household members about every 2 years, with the latest survey (wave 5) completed in 2017 involving 37,368 individuals in 13,719 households. Due to attrition over the waves, a top-up sample was added during the wave 5 survey in 2017 to maintain the representativeness of the sample [36]. For this paper, we analyzed a sub-sample of subsistence farming households. These are households that indicated that they had participated in subsistence farming activities over the previous 12 months before the interview. These farming activities exclude those that household members engaged in for employment purposes. The last two columns of Table 1 present, respectively, the number and proportion of farming households per wave. The farming households, on average, constitute about $11 \%$ of the total sample of households. However, this has varied over the years (it was not clear from the data and supporting documents 
why the proportion of farming households varied this much across the waves, especially the big drop from wave 1 to wave 2 of the NIDS data), with farming households contributing $18 \%$ during wave 1 , and about $5 \%$ during wave 2 . In the last wave, farming households constituted about $10 \%$ of the surveyed households.

Table 1. Number of farming households by wave, wave 1-5.

\begin{tabular}{ccccc}
\hline Wave & Year & $\begin{array}{c}\text { Total Number } \\
\text { of Households }\end{array}$ & $\begin{array}{c}\text { Number of Farming } \\
\text { Households }\end{array}$ & $\begin{array}{c}\text { Proportion of Farming } \\
\text { Households (\%) }\end{array}$ \\
\hline Wave 1 & 2008 & 7296 & 1280 & 17.54 \\
Wave 2 & $2010-2011$ & 9125 & 491 & 5.38 \\
Wave 3 & 2012 & 10,218 & 843 & 8.25 \\
Wave 4 & $2014-2015$ & 11,888 & 1502 & 12.63 \\
Wave 5 & 2017 & 13,719 & 1369 & 9.98 \\
Pooled & & 52,246 & 5485 & Average: 10.50 \\
Total & & & & \\
\hline
\end{tabular}

The NIDS survey instruments include household and individual (adult and child) questionnaires, which collect information on household characteristics (household size, location, consumption of various foods, assets, etc.) and individual characteristics of household members (e.g., age, gender, education levels, etc.).

\subsection{Variables}

The variables that were considered in this study are presented in Table 2. Household dietary diversity score (HDDS), and the consumption of fruits or vegetables, were the dependent variables. HDDS was measured by adding the food groups consumed by households in a specific period [38-40]. The set of foods grouped together share similar nutritional properties or biological characteristics [35,41]. HDDS measures the economic ability of a household to access a variety of foods [39], and higher levels of HDDS imply improved chances of a household to consume enough of all food components necessary for good health [27]. However, HDDS should not be interpreted as a measure of nutrition or diet quality, as it is possible for household to lack crucial micronutrients even when consuming a diverse diet $[18,35]$.

Table 2. Variables and their description.

\begin{tabular}{|c|c|}
\hline Variable Name & Variable Description \\
\hline \multicolumn{2}{|l|}{ Dependent Variables } \\
\hline HDDS & Household dietary diversity score (count of food groups) \\
\hline $\operatorname{Veg}(1=$ yes $)$ & Consumed vegetables $(1=$ yes $)$ \\
\hline Fruit $(1=$ yes $)$ & Consumed fruits $(1=$ yes $)$ \\
\hline \multicolumn{2}{|l|}{ Independent variables } \\
\hline FPDI & Farm production diversity index (count of food groups) \\
\hline Age & Age of household head (years) \\
\hline Sex $(1=$ male $)$ & Sex of household head $(1=$ male, $0=$ female $)$ \\
\hline Household size & Number of members in the household \\
\hline Education (years) & Years of schooling of household head (years) \\
\hline Employed $(1=$ yes $)$ & Employment status of household head \\
\hline Income_ca & Total household income/capita (rands) \\
\hline Food_exp_ca & Total food expenditure/capita (rands) \\
\hline Urban $(1=$ urban $)$ & $\begin{array}{c}\text { Geographical location }(1=\text { urban, } 0=\text { farm or traditional } \\
\text { settlement) }\end{array}$ \\
\hline
\end{tabular}

HDDS was constructed using the number of food groups consumed by the household over the past 30 days. While HDDS is often calculated using the $24 \mathrm{~h}$ or 7 -day recall periods, our paper relied on a 30-day period to construct the index, as the NIDS data used this recall 
period. Several studies have also used the 30-day recall period (e.g., [42-44]). The food items were categorized into 12 different food groups: A. cereals; B. roots and tubers; C. vegetables; D. fruits; E. meat; F. eggs; G. fish and seafood; H. pulses and nuts; I. milk and milk products; J. oils and fats; K. sugars; and L. condiments [40]. From wave 3, households that were asked to respond to detailed questions about consumption activities were those who either spend more than $80 \%$ on food or those who spent at most $5 \%$. As such, the sample for the HDDS variable was significantly reduced from wave 3 onwards.

The consumption of fruits and vegetables was used to assess the access by households to micronutrient-rich foods. As explained above, achieving a high dietary diversity score does not guarantee that important food groups, such as fruits and vegetables, are included in the diet [45]. Further, factors correlated with dietary diversity do not always correlate with specific food groups such as fruit and vegetable consumption [16,25,45]. For example, whereas the correlation between farm production diversity and dietary diversity scores was significant and positive in Jones et al [25], there was an insignificant association between the consumption of fruits and vegetables and farm production diversity. As Sibhatu and Qaim [45] argued, the literature should investigate nutrition using other dietary indicators, such as the consumption of fruits and vegetables, which are important sources of micronutrients. The consumption of fruits and vegetables was captured using binary variables indicating that fruits and vegetables were consumed by a household during the previous 30 days before the survey. The dataset used in this paper does not capture the frequency and size of the servings of fruits and vegetables consumed by households, meaning that we do not have precise indicators of the frequency and amounts of fruits and vegetables consumed. In addition, we were unable to study the intra-household consumption dynamics using the available data.

The farm production diversification (FPDI) was constructed as a simple count of 9 unique food groups produced by a household in the past 12 months. The food groups included were like the ones used for the calculation of the HDDS. The crop and animal species were categorized into 9 food groups-cereals, roots and tubers, vegetables, fruits, meat, eggs, pulses and nuts, milk and milk products, and herbs or other. Excluded in the FPDI were fish and seafood, oils and fats, sugars, and condiments, which no farm household produced. The use of a food group-based index, instead of the crop and animal species count, ensures that both HDDS and FPDI are measured using a similar scale, which will improve the results (see Verger et al. [34] for a review of different production diversity indicators). As argued in Berti [46], it is more important, in terms of improving nutrition through production diversity, that foods from different food groups are produced, not just that different species are produced. Using a species count, a household that produces maize, rice, wheat, and barley would be considered to have a production diversity of 4 . This would be considered the same as a household that produces maize, spinach, beans, and raises chickens, whose production diversity score would also be 4 . The latter household clearly would have a more diverse diet than the former household, whose choice is only among cereals.

Total household income captures monthly income received by the household from a variety of sources, such as the labor market, government grants, remittances, investments, and subsistence farming activities. The variable was expected to have a non-linear correlation with dietary diversity and nutrition. The diet response of poor households to income increases was expected to be different from that of richer households. Food expenditure was used to capture the extent of household market integration, i.e., the dependence on local markets for increasing the range in the food consumed. Food expenditure provides a more direct measure of a household's dependence on markets for food [47]. Households located in urban areas were expected to have more diverse diets compared to those located in rural settings (farms or traditional settlements) because those in urban areas have relatively easier access to markets with diverse food types. 


\subsection{Empirical Model}

The panel regression model that was implemented to investigate the impact of farm production diversity on dietary diversity and nutrition indicators was specified as follows:

$$
\mathrm{HDDS}_{i \mathrm{t}}=\beta_{0}+\beta_{1} \mathrm{FPDI}_{\mathrm{it}}+\beta_{2} X_{\mathrm{it}}+\varepsilon_{\mathrm{it}}
$$

where $\mathrm{HDDS}_{\mathrm{it}}$ is the household dietary diversity index for household $i$ at time $t, \mathrm{X}_{\mathrm{it}}$ is a vector of socio-economic characteristics of household $i$ and time $t$ (such as household head, age, gender, education, household size, income level, etc.); the $\beta$ are the coefficients to be estimated, and $\varepsilon_{i t}$ is the error term. The random-effects logit models were estimated for the binary outcomes of fruit or vegetable consumption using the same specifications in Equation (1).

Equation (1) was estimated in Stata 15 using the random effects (RE) estimator. The RE estimator requires that FPDI be uncorrelated with any unobserved factors that may also impact HDDS to produce consistent estimates [48]. If there is a correlation, the RE estimator produces inconsistent estimates, and one would need to use the fixed effects estimators [49]. The Hausman test was completed, and it showed that there was no significant difference between the RE and FE estimators. The Breusch and Pagan Lagrange multiplier tests, which test if the random-effects model is appropriate, were completed to choose between the pooled OLS and random-effects models. The BP Lagrange multiplier tests supported the Hausman test, indicating that there were random effects, and thus the use of the random effects model is preferred over the pooled OLS model. As such, the use of RE was preferred, as it produces consistent and more efficient estimates. Additionally, the RE estimator allows for the estimations of coefficients of the time-invariant variables (e.g., gender). Robust standard errors were reported. We did not weigh the analysis, given that the RE model does not allow for varying weights within panel units. Therefore, the discussion and conclusions below may not be generalizable to the entire population.

\section{Results and Discussions}

\subsection{Descriptive Statistics}

Table 3 presents the summary statistics of the key variables considered in this study, focusing on the 2583 farming households who reported consumption data (i.e., had an HDDS score). Table 3 shows that the farm household heads were on average 55 years old, and $43 \%$ of them were males. On average, the household heads completed over 5 years of schooling, and their households had about five members. About half of the household heads were employed. The households reported generating an income of over 1200 ZAR per capita in a month. The farm households spent 242 ZAR per capita on food. Most of the farming households $(80 \%)$ were located in traditional settlements or farms, while $20 \%$ of the farm households were located in urban areas.

The farm households consumed 9 out of 12 food groups on average $(\min =1 ; \max =12)$. The results show that dietary diversity has been on a declining trend, from above nine food groups during wave 2 to about eight food groups during wave 5 . About $70 \%$ of the households consumed vegetables, while $38 \%$ consumed fruits. While the NIDS data do not allow us to analyze the frequency of fruit and vegetable consumption per day, these figures suggest low levels of fruit and vegetable consumption, especially of fruits. Other studies have reported similarly low levels of fruit and vegetable consumption in South Africa [3,50-53]. The proportion of farm households consuming vegetables has been on an increasing trend, except for a decline during wave 4 (2014-2015). The proportion of households consuming vegetables increased from 0.68 during wave 1 (2008) to 0.78 during wave 5 (2017). However, while the rising proportion of households consuming vegetables is commendable, this leaves a low proportion of vegetable consumption, given that there was $22 \%$ of households who did not consume any vegetables over a period of 30 days. The percentage of households consuming fruits has remained below 50\% across the waves and has been characterized by fluctuations over time. 
Table 3. Summary statistics $(n=2583)$.

\begin{tabular}{|c|c|c|c|c|c|c|}
\hline \multirow[t]{2}{*}{ Variables } & Pooled & $\begin{array}{l}\text { Wave } 1 \\
(2008)\end{array}$ & $\begin{array}{c}\text { Wave } 2 \\
(2010-2011)\end{array}$ & $\begin{array}{l}\text { Wave } 3 \\
(2012)\end{array}$ & $\begin{array}{c}\text { Wave } 4 \\
(2014-2015)\end{array}$ & $\begin{array}{l}\text { Wave } 5 \\
(2017)\end{array}$ \\
\hline & $\begin{array}{c}\text { Mean } \\
\text { (Std. Dev) }\end{array}$ & $\begin{array}{l}\text { Mean (Std. } \\
\text { Dev) }\end{array}$ & $\begin{array}{c}\text { Mean } \\
\text { (Std. Dev) }\end{array}$ & $\begin{array}{c}\text { Mean } \\
\text { (Std. Dev) }\end{array}$ & $\begin{array}{c}\text { Mean } \\
\text { (Std. Dev) }\end{array}$ & $\begin{array}{c}\text { Mean } \\
\text { (Std. Dev) }\end{array}$ \\
\hline \multicolumn{7}{|c|}{ Dependent variables } \\
\hline HDDS & $\begin{array}{c}8.89 \\
(2.75)\end{array}$ & $\begin{array}{l}8.97 \\
(2.26)\end{array}$ & $\begin{array}{c}9.37 \\
(2.50)\end{array}$ & $\begin{array}{c}9.27 \\
(3.13)\end{array}$ & $\begin{array}{c}7.80 \\
(3.53)\end{array}$ & $\begin{array}{c}8.31 \\
(3.44)\end{array}$ \\
\hline Veg (1 = yes) & $\begin{array}{c}0.70 \\
(0.46)\end{array}$ & $\begin{array}{c}0.68 \\
(0.47)\end{array}$ & $\begin{array}{c}0.68 \\
(0.47)\end{array}$ & $\begin{array}{c}0.77 \\
(0.42)\end{array}$ & $\begin{array}{c}0.70 \\
(0.46)\end{array}$ & $\begin{array}{c}0.78 \\
(0.42)\end{array}$ \\
\hline Fruit (1 = yes) & $\begin{array}{c}0.38 \\
(0.49)\end{array}$ & $\begin{array}{c}0.32 \\
(0.47)\end{array}$ & $\begin{array}{c}0.46 \\
(0.50)\end{array}$ & $\begin{array}{c}0.49 \\
(0.50)\end{array}$ & $\begin{array}{c}0.37 \\
(0.48)\end{array}$ & $\begin{array}{c}0.45 \\
(0.50)\end{array}$ \\
\hline \multicolumn{7}{|c|}{ Explanatory variables } \\
\hline FPDI & $\begin{array}{c}2.46 \\
(1.29)\end{array}$ & $\begin{array}{l}2.28 \\
(1.23)\end{array}$ & $\begin{array}{c}2.62 \\
(1.60)\end{array}$ & $\begin{array}{c}2.79 \\
(1.53)\end{array}$ & $\begin{array}{c}2.51 \\
(1.34)\end{array}$ & $\begin{array}{c}2.73 \\
(1.50)\end{array}$ \\
\hline Age (years) & $\begin{array}{c}54.60 \\
(15.14)\end{array}$ & $\begin{array}{c}56.54 \\
(14.90)\end{array}$ & $\begin{array}{c}55.10 \\
(14.76)\end{array}$ & $\begin{array}{c}49.41 \\
(15.28)\end{array}$ & $\begin{array}{c}53.91 \\
(15.35)\end{array}$ & $\begin{array}{c}54.60 \\
(15.35)\end{array}$ \\
\hline $\operatorname{Sex}(1=$ male $)$ & $\begin{array}{c}0.43 \\
(0.50)\end{array}$ & $\begin{array}{c}0.48 \\
(0.50)\end{array}$ & $\begin{array}{c}0.42 \\
(0.49)\end{array}$ & $\begin{array}{l}0.37 \\
(48)\end{array}$ & $\begin{array}{c}0.38 \\
(0.49)\end{array}$ & $\begin{array}{c}0.36 \\
(0.48)\end{array}$ \\
\hline Household size & $\begin{array}{c}5.12 \\
(3.03)\end{array}$ & $\begin{array}{c}5.17 \\
(3.06)\end{array}$ & $\begin{array}{c}5.35 \\
(3.19)\end{array}$ & $\begin{array}{l}5.16 \\
(2.87)\end{array}$ & $\begin{array}{c}4.40 \\
(2.76)\end{array}$ & $\begin{array}{c}5.11 \\
(2.87)\end{array}$ \\
\hline Education (years) & $\begin{array}{c}5.25 \\
(4.57)\end{array}$ & $\begin{array}{c}4.39 \\
(4.46)\end{array}$ & $\begin{array}{c}5.22 \\
(4.51)\end{array}$ & $\begin{array}{c}6.13 \\
(4.64)\end{array}$ & $\begin{array}{c}6.50 \\
(4.36)\end{array}$ & $\begin{array}{c}6.75 \\
(4.47)\end{array}$ \\
\hline Employed (1 = yes) & $\begin{array}{c}0.50 \\
(0.50)\end{array}$ & $\begin{array}{c}0.54 \\
(0.50)\end{array}$ & $\begin{array}{c}0.36 \\
(0.48)\end{array}$ & $\begin{array}{c}0.52 \\
(0.50)\end{array}$ & $\begin{array}{c}0.52 \\
(0.50)\end{array}$ & $\begin{array}{c}0.51 \\
(0.50)\end{array}$ \\
\hline Income_ca (ZAR) & $\begin{array}{c}1202.76 \\
(2625.70)\end{array}$ & $\begin{array}{c}825.84 \\
(1623.29)\end{array}$ & $\begin{array}{c}1101.35 \\
(2294.86)\end{array}$ & $\begin{array}{c}1107.01 \\
(1685.59)\end{array}$ & $\begin{array}{c}2122.52 \\
(4457.43)\end{array}$ & $\begin{array}{c}2187.77 \\
(4098.79)\end{array}$ \\
\hline Food_exp_ca (ZAR) & $\begin{array}{c}242.72 \\
(276.91)\end{array}$ & $\begin{array}{c}204.87 \\
(197.60)\end{array}$ & $\begin{array}{c}261.15 \\
(317.28)\end{array}$ & $\begin{array}{c}251.81 \\
(293.65)\end{array}$ & $\begin{array}{c}288.88 \\
(383.19)\end{array}$ & $\begin{array}{c}320.67 \\
(338.16)\end{array}$ \\
\hline Urban $(1=$ urban $)$ & $\begin{array}{c}0.20 \\
(0.40)\end{array}$ & $\begin{array}{c}0.14 \\
(0.35)\end{array}$ & $\begin{array}{c}0.26 \\
(0.44)\end{array}$ & $\begin{array}{c}0.21 \\
(0.41)\end{array}$ & $\begin{array}{c}0.31 \\
(0.46)\end{array}$ & $\begin{array}{c}0.20 \\
(0.40)\end{array}$ \\
\hline
\end{tabular}

Note: 1 USD = 14.35 ZAR as of September 2021.

The farm households produced just over two food groups ( $\min =1 ; \max =8)$, which suggests that most of the food consumed by the households is sourced from the market. Farm production diversity also remained largely constant over time during the period. Figure 1 presents the proportion of households that produced the different food groups. The figure shows that most households were involved in rearing different animals (such as cattle, goats, chickens, etc.) for meat, followed by cereal production. A significant proportion $(36 \%)$ of the households produced vegetables, while less than $8 \%$ of the households produced fruits. There were also few subsistence households that produced milk, while just over a quarter of the households produced eggs.

\subsection{Empirical Results}

Table 4 presents the results of the random-effects model. Model 1 was estimated with only farm production diversity and without controls, and Model 2 introduced the controls. The results show that farm production diversity was positively correlated with household dietary diversity, implying that increasing farm production diversification is positively and significantly associated with dietary diversity. This suggests that households that produce a diverse range of crops and animals consume diverse diets. However, the magnitude of the association was found to be relatively small. Specifically, increasing production diversity by one food group would lead to an increase in HDDS of about 0.11 food groups. In other words, the households would require the food groups produced to increase by over nine times to consume an additional food group. Our results are in line with most previous studies that report a modest magnitude between associations in the range of 0.05 to $0.30[12,25,29,47,54,55]$. These results highlight that while one's own production is 
important in improving dietary diversity among subsistence households in South Africa, achieving higher levels of dietary diversity requires other strategies. Households who spend more on food were more likely to consume a more diverse diet than those who spend less, suggesting that market integration is associated with higher dietary diversity. Moreover, we used the food expenditures measure market integration. This highlights the crucial function of markets in complementing their own farm production and resonates with recent studies [56-59].

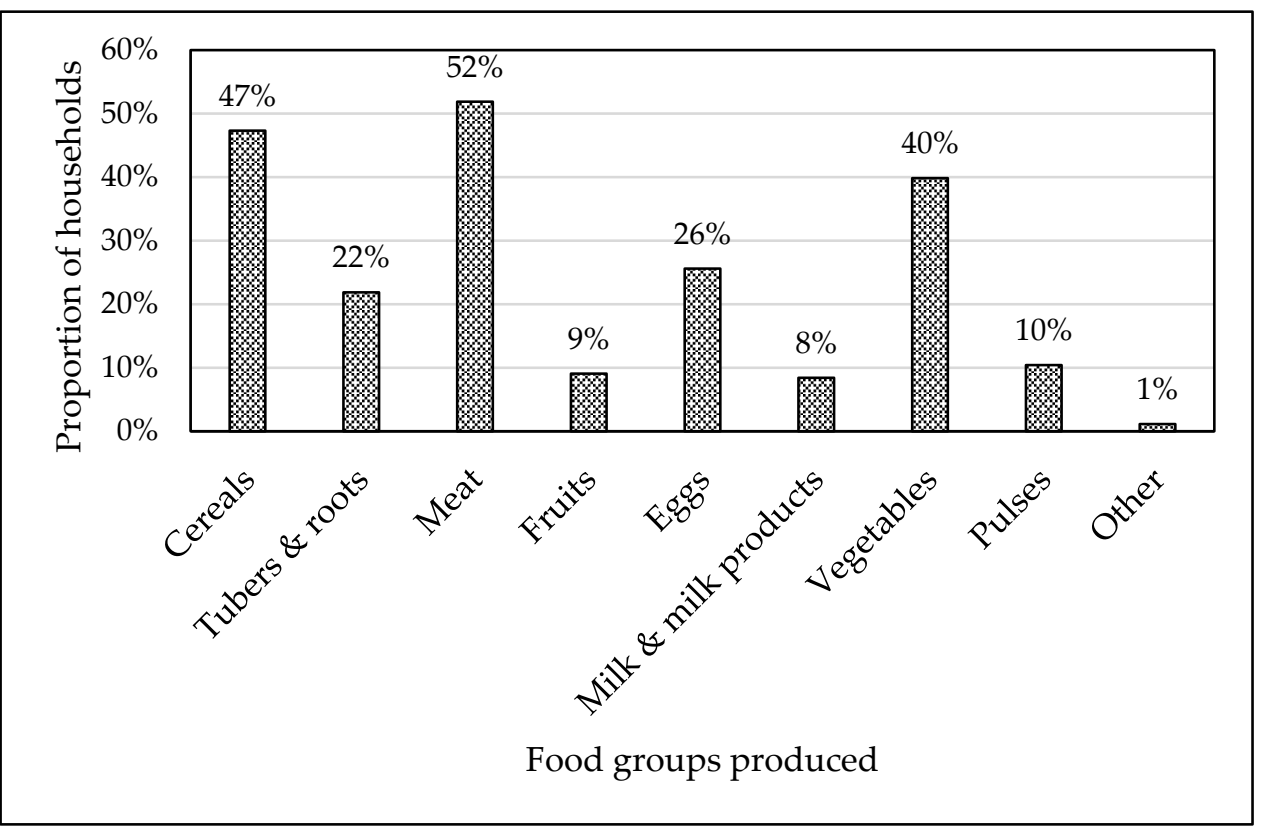

Figure 1. Number of food groups produced by farm households across all 5 waves $(n=2583)$.

The results show that dietary diversity varied by different demographic and socioeconomic characteristics of households. The age of the household head was positively correlated with dietary diversity, which suggests that as heads become older, they are more likely to become more alert about their diets due to other old-age-related health challenges that they are likely to be having. This is in line with several studies (e.g., $[12,29,31,44,60]$ ), who found a positive correlation between age and dietary diversity, and contrary to some studies (e.g., $[18,57,59,61])$ that reported a negative relationship. In line with various studies (e.g., $[12,18,31,47,62])$, the results indicated that households with more household members had higher HDDS. This could be because various members of the same household require more and diverse foods based on their personal preferences.

The level of education of the household head was strongly and positively associated with increased dietary diversity. High levels of education imply that these household heads can easily understand and interpret health and nutrition information knowledge, and thus they understand the importance of diverse diets. This was in line with expectations and most of the studies in the literature [18,21,29,63-65]. Households with employed heads consumed more diverse diets, highlighting the crucial role of generating employment opportunities for households in South Africa. This result resonates and concurs with various studies that reported a positive relationship between household head's employment and diverse diets [66-69]. 
Table 4. Association between farm production diversification and dietary diversity: random-effects model results.

\begin{tabular}{|c|c|c|c|c|}
\hline \multicolumn{3}{|c|}{1} & \multicolumn{2}{|l|}{2} \\
\hline Variables & Coef. & Std. Err. & Coef. & Std. Err. \\
\hline FPDI & $0.089 * *$ & 0.042 & $0.111^{* *}$ & 0.044 \\
\hline Food_exp_ca (ZAR) & & & $0.003^{* * *}$ & 0.0006 \\
\hline Age & & & $0.021^{* * *}$ & 0.005 \\
\hline Sex $(1=$ male $)$ & & & -0.039 & 0.119 \\
\hline Household size & & & $0.152 * * *$ & 0.025 \\
\hline Education (years) & & & $0.093^{* * *}$ & 0.019 \\
\hline Employed (1 = yes) & & & $0.529^{* * *}$ & 0.124 \\
\hline Income_ca (000 ZAR) & & & $-0.144^{* *}$ & 0.062 \\
\hline Income/ca squared (000 ZAR) & & & $2.46 \times 10^{-6 * * *}$ & $1.09 \times 10^{-6}$ \\
\hline Urban $(1=$ urban $)$ & & & $1.133^{* * *}$ & 0.167 \\
\hline \multicolumn{5}{|l|}{ Wave } \\
\hline 2 & & & 0.160 & 0.146 \\
\hline 3 & & & 0.079 & 0.213 \\
\hline 4 & & & $-1.501^{* * *}$ & 0.262 \\
\hline 5 & & & $-1.262^{* * *}$ & 0.231 \\
\hline _constant & $8.613^{* * *}$ & 0.122 & $5.281^{* * *}$ & 0.391 \\
\hline sigma_u & 0.478 & & 0.714 & \\
\hline sigma_e & 2.657 & & 2.421 & \\
\hline rho & 0.0313 & & 0.080 & \\
\hline$n$ & 2263 & & 1972 & \\
\hline Wald $\chi^{2}$ & Wald $\chi_{* *}^{2}(1)=4.53$ & & \multicolumn{2}{|c|}{ Wald $\chi^{2}(14)=302.06^{* * *}$} \\
\hline Overall $R^{2}$ & 0.002 & & \multicolumn{2}{|l|}{0.18} \\
\hline $\begin{array}{l}\text { Hausman tests: } \\
\text { Breusch and Pagan Lagrang }\end{array}$ & $\begin{array}{l}(10)=12.32, p=0.2 \\
\text { multiplier test for }\end{array}$ & n effects: & \multicolumn{2}{|c|}{$\chi^{2} \operatorname{bar}(01)=8.83, p=0.0015$} \\
\hline
\end{tabular}

Notes and meaning: ${ }^{* * *}$ and ${ }^{* *}$ means significant at $1 \%$ and $5 \%$ levels, respectively.

The relationship between income per capita and diet diversity was non-linear. At lower income levels, increasing income was associated with declining diversity of diets. Banerjee and Duflo [70] argued that poor people do not always rationally increase their food consumption when they have increased income. The study further explained that for poor households who had increased income, obtaining more calories or a diverse diet was not a priority; obtaining tastier foods was. In contrast, at higher income levels, increasing incomes led to an increase in diet quality. Several studies document the positive effect of income on increased household food consumption [18,29,63,65,71], suggesting the important role of promoting income-generating activities among households. The results also show that geographic location plays a role in dietary diversity. Households residing in urban areas consumed more diverse diets than those located in rural settings (farms or traditional settlements). This is in line with several studies that showed a positive association between the two $[57,65]$. This may suggest that households residing in urban areas have more opportunities in terms of physical access to markets and are potentially able to purchase different food items. The time variables show that there was a significant decrease in dietary diversity in waves 4 and 5 compared to wave 1 .

Table 5 presents the results estimated to assess the relationship between farm diversity and the likelihood of fruit and vegetable consumption. The results show no significant relationship between farm production and fruit or vegetable consumption. These results suggest that farm production has a limited effect in increasing the consumption of micronutrient-rich diets, such as fruits and vegetables. 
Table 5. Association between production diversification and fruit and vegetable consumption; random effects logit model results.

\begin{tabular}{|c|c|c|c|c|}
\hline \multirow[t]{2}{*}{ Variables } & \multicolumn{2}{|c|}{ Fruit Consumption } & \multicolumn{2}{|c|}{ Vegetable Consumption } \\
\hline & Coef. & Std. Err. & Coef. & Std. Err. \\
\hline FPDI & 0.025 & 0.037 & 0.004 & 0.038 \\
\hline Food_exp_ca (ZAR) & $0.003^{* * *}$ & 0.001 & $0.003^{* * *}$ & 0.001 \\
\hline Age & 0.007 & 0.005 & $0.014^{* * *}$ & 0.004 \\
\hline $\operatorname{Sex}(1=$ male $)$ & 0.050 & 0.108 & 0.038 & 0.108 \\
\hline Household size & $0.094^{* * *}$ & 0.025 & $0.084^{* * *}$ & 0.023 \\
\hline Education (years) & $0.069^{* * *}$ & 0.017 & $0.050 * * *$ & 0.016 \\
\hline Employed $(1=$ yes $)$ & $0.347^{* * *}$ & 0.117 & $0.204 *$ & 0.111 \\
\hline Income_ca ('000 ZAR) & 0.003 & 0.061 & $-0.228^{* *}$ & 0.099 \\
\hline $\begin{array}{c}\text { Income_ca squared } \\
\text { (‘000 ZAR) }\end{array}$ & $-8.30 \times 10^{-8}$ & $1.12 \times 10^{-6}$ & 0.000 & $6.94 \times 10^{-6}$ \\
\hline \multicolumn{5}{|l|}{ Wave } \\
\hline 2 & $0.493^{* * *}$ & 0.153 & -0.072 & 0.139 \\
\hline 3 & $0.699 * * *$ & 0.179 & $0.448^{* *}$ & 0.187 \\
\hline 4 & 0.100 & 0.193 & 0.086 & 0.192 \\
\hline 5 & 0.254 & 0.177 & 0.277 & 0.194 \\
\hline _constant & $-3.199 * * *$ & 0.434 & $-1.313^{* * *}$ & 0.331 \\
\hline$/ \operatorname{lnsig} 2 \mathrm{u}$ & -3.064 & 9.556 & -3.820 & 16.052 \\
\hline sigma_u & 0.216 & 1.033 & 0.148 & 1.188 \\
\hline rho & 0.014 & 0.132 & 0.007 & 0.106 \\
\hline$n$ & \multicolumn{2}{|c|}{1972} & \multicolumn{2}{|c|}{1966} \\
\hline Wald $\chi^{2}$ & \multicolumn{2}{|c|}{ Wald $\chi^{2}(14)=84.25^{* * *}$} & \multicolumn{2}{|c|}{ Wald $\chi^{2}(14)=69.71^{* * *}$} \\
\hline
\end{tabular}

Notes and meaning: ${ }^{* * *}, * *, *$ means significant at $1 \%, 5 \%$ and $10 \%$ levels, respectively.

\section{Conclusions}

The present study assessed farm production diversity and its correlation with household dietary diversity in South Africa using the NIDS data. NIDS is a nationally representative household panel survey, which currently has five waves. The analysis focused on a subsample of farming households. We estimated the random-effects regression model and found a positive relationship between farm production diversity and household dietary diversity in South Africa. Further, dietary diversity was positively associated with increased market integration, indicating that promoting farm production diversification complemented by market integration are potential strategies to improve household dietary diversity in South Africa. However, the association between farm production diversity and fruit consumption was insignificant, suggesting that farm production diversity does not play a significant role in improving the consumption of fruits or vegetables. The results imply that while increasing farm production diversity might lead to the consumption of a diverse range of foods, it might not significantly lead to increased intake of micronutrientrich foods such as fruits and vegetables. Factors such as household head employment status, education level, and income opportunities were equally important in enhancing household dietary diversity in South Africa.

Results from this study have significant implications for programming and policy. First, the results imply that interventions to increase household dietary diversity in South Africa should be anchored on both promoting farm production diversification as well as access to the markets. There is a need for the current agriculture support and nutrition support programs to work in tandem in promoting the production and consumption of diverse crop and livestock species in South Africa to ensure an adequate supply of nutrients. Hence, the public and private sectors in South Africa should consider farm production diversification as one of the priorities on the nutrition agenda. Second, policies and interventions should promote the spread of modern food chains to rural areas to 
enhance market integration by subsistence households. Not only is the penetration of modern food chains into rural areas important as potential markets where these subsistence households might sell their surplus output, but is are also crucial in supplying a diverse range of foods that the households can buy to improve the diversity of their diets. The results have shown that subsistence farming on its own will not be enough to support the level of diversification required to improve the diets of these households. Third, the programs to support employment and income-generating opportunities are crucial for improved household dietary diversity. Furthermore, specific awareness programs should be implemented to educate people on the importance of consuming micro-nutrient foods such as fruits and vegetables.

Author Contributions: Conceptualization, S.S., C.N. and C.O.N.; methodology, S.S. and C.O.N.; software, S.S. and C.O.N.; validation, C.M., S.A.S. and A.M.N.; formal analysis, S.S. and C.O.N.; investigation, S.S., S.A.S. and A.M.N.; resources, S.S. and C.N.; writing-original draft preparation, S.S., C.M., A.M.N., S.A.S. and C.N.; writing-review and editing, S.S., C.M., A.M.N., S.A.S. and C.O.N.; visualization, S.S.; project administration, S.S. and C.N.; funding acquisition, C.N. All authors have read and agreed to the published version of the manuscript.

Funding: This research was funded by the International Development Research Centre (IDRC), grant number 108649-001.

Institutional Review Board Statement: This paper relied on the NIDS data, which is publicly available at this website: www.nids.uct.ac.za (accessed on 28 August 2021). The NIDS was conducted according to the guidelines of the Declaration of Helsinki, and received ethical clearance from the Commerce Faculty Ethics Committee of the University of Cape Town (see https:/ / www.datafirst.uct. ac.za/dataportal/index.php/catalog/713 accessed on 28 August 2021). Therefore, this paper did not require a separate ethics approval. However, this paper is part of a project that received an ethics approval from the Human Sciences Research Council Research Ethics Committee (Protocol No REC 5/20/03/19) on the 5 July 2019.

Informed Consent Statement: The NIDS data collectors obtained informed consent from all subjects involved in the study. The data coming in from the field were accepted as valid only if NIDS has a signed consent form for each interview that produced the data. Written informed consent for publication of this paper is not applicable.

Data Availability Statement: The data supporting the reported results are available with the data files on DataFirst's data site: https: / /www.datafirst.uct.ac.za/dataportal/index.php/catalog/NIDS / about (accessed on 28 August 2021), and also on the National Income Dynamics Study (NIDS) website: www.nids.uct.ac.za (accessed on 28 August 2021).

Conflicts of Interest: The authors declare no conflict of interest. The funders had no role in the design of the study; in the collection, analyses, or interpretation of data; in the writing of the manuscript, or in the decision to publish the results.

\section{References}

1. Ndinda, C.; Ndhlovu, T.P.; Juma, P.; Asiki, G.; Kyobutungi, C. The Evolution of Non-Communicable Diseases Policies in Post-Apartheid South Africa. BMC Public Health 2018, 18, 956. [CrossRef]

2. Stats, S.A. Mortality and Causes of Death in South Africa, 2015: Findings from Death Notification; Statistics South Africa: Pretoria, South Africa, 2017.

3. Sinyolo, S.; Ndinda, C.; Murendo, C.; Sinyolo, S.A.; Neluheni, M. Access to Information Technologies and Consumption of Fruits and Vegetables in South Africa: Evidence from Nationally Representative Data. Int. J. Environ. Res. Public Health 2020, 17, 4880. [CrossRef]

4. Swinburn, B.A.; Kraak, V.I.; Allender, S.; Atkins, V.J.; Baker, P.I.; Bogard, J.R.; Brinsden, H.; Calvillo, A.; De Schutter, O.; Devarajan, R.; et al. The Global Syndemic of Obesity, Undernutrition, and Climate Change: The Lancet Commission Report. Lancet 2019, 393, 791-846. [CrossRef]

5. FAO; IFAD; UNICEF; WFP; WHO. The State of Food Security and Nutrition in the World 2021. Transforming Food Systems for Food Security, Improved Nutrition and Affordable Healthy Diets for All; Food Agriculture Organisation of the United Nations: Rome, Italy, 2021. 
6. Otterbach, S.; Rogan, M. Spatial Differences in Stunting and Household Agricultural Production in South Africa: (Re-)Examining the Links Using National Panel Survey Data; Discussion Paper Series IZA DP No. 11008; IZA-Institute of Labor Economics, University of Bonn: Bonn, Germany, 2017.

7. Pereira, L.M.; Cuneo, C.N.; Twine, W.C. Food and Cash: Understanding the Role of the Retail Sector in Rural Food Security in South Africa. Food Sec. 2014, 6, 339-357. [CrossRef]

8. McLachlan, M.; Landman, A.P. Nutrition-Sensitive Agriculture-A South African Perspective. Food Sec. 2013, 5, 857-871. [CrossRef]

9. Feeley, A.; Kahn, K.; Twine, R.; Norris, S. Exploratory Survey of Informal Vendor-Sold Fast Food in Rural South Africa. S. Afr. J. Clin. Nutr. 2011, 24, 199-201. [CrossRef]

10. Hendriks, S. Food Security in South Africa: Status Quo and Policy Imperatives. Agrekon 2014, 53, 1-24. [CrossRef]

11. Devereux, S.; Waidler, J. Why Does Malnutrition Persist in South Africa Despite Social Grants; Food Security SA Working Paper Series No.001; DST-NRF Centre of Excellence in Food Security, University of the Western Cape: Cape Town, South Africa, 2017.

12. Muthini, D.; Nzuma, J.; Nyikal, R. Farm Production Diversity and its Association with Dietary Diversity in Kenya. Food Sec. 2020, 12, 1107-1120. [CrossRef]

13. Siwela, M.; Pillay, K.; Govender, L.; Lottering, S.; Mudau, F.N.; Modi, A.T.; Mabhaudhi, T. Biofortified Crops for Combating Hidden Hunger in South Africa: Availability, Acceptability, Micronutrient Retention and Bioavailability. Foods 2020, 9, 815. [CrossRef]

14. Govender, L.; Pillay, K.; Siwela, M.; Modi, A.; Mabhaudhi, T. Food and Nutrition Insecurity in Selected Rural Communities of KwaZulu-Natal, South Africa-Linking Human Nutrition and Agriculture. Int. J. Environ. Res. Public Health 2016, 14, 17. [CrossRef]

15. Hendriks, S.L.; Viljoen, A.; Marais, D.; Wenhold, F.A.; McIntyre, A.M.; Ngidi, M.S.; Annandale, J.G.; Kalaba, M.; Stewart, D. Considerations for the Design of Nutrition-Sensitive Production Programmes in Rural South Africa. BMC Public Health 2020, 20, 1383. [CrossRef] [PubMed]

16. Sibhatu, K.T.; Qaim, M. Review: Meta-Analysis of the Association between Production Diversity, Diets, and Nutrition in Smallholder Farm Households. Food Policy 2018, 77, 1-18. [CrossRef]

17. Jones, A.D. Critical Review of the Emerging Research Evidence on Agricultural Biodiversity, Diet Diversity, and Nutritional Status in Low- and Middle-Income Countries. Nutr. Rev. 2017, 75, 769-782. [CrossRef] [PubMed]

18. Chegere, M.J.; Stage, J. Agricultural Production Diversity, Dietary Diversity and Nutritional Status: Panel Data Evidence from Tanzania. World Dev. 2020, 129, 104856. [CrossRef]

19. Uccello, E.; Kauffmann, D.; Calo, M.; Streissel, M. Nutrition-Sensitive Agriculture and Food Systems in Practice: Options for Intervention; Food and Agriculture Organization of the United Nations: Rome, Italy, 2017.

20. Kihiu, E.N.; Amuakwa-Mensah, F. Agricultural Market Access and Dietary Diversity in Kenya: Gender Considerations towards Improved Household Nutritional Outcomes. Food Policy 2021, 100, 102004. [CrossRef]

21. United Nations. Transforming Our World: The 2030 Agenda for Sustainable Development. Available online: https:// sustainabledevelopment.un.org/post2015/transformingourworld/publication (accessed on 26 November 2019).

22. Ruel, M.T.; Quisumbing, A.R.; Balagamwala, M. Nutrition-Sensitive Agriculture: What Have We Learned So Far? Glob. Food Sec. 2018, 17, 128-153. [CrossRef]

23. Islam, A.H.; von Braun, J.; Thorne-Lyman, A.L.; Ahmed, A.U. Farm Diversification and Food and Nutrition Security in Bangladesh: Empirical Evidence from Nationally Representative Household Panel Data. Food Secur. 2018, 10, 701-720. [CrossRef]

24. Habtemariam, L.T.; Gornott, C.; Hoffmann, H.; Sieber, S. Farm Production Diversity and Household Dietary Diversity: Panel Data Evidence from Rural Households in Tanzania. Front. Sustain. Food Syst. 2021, 5, 151. [CrossRef]

25. Jones, A.D.; Shrinivas, A.; Bezner-Kerr, R. Farm Production Diversity is Associated with Greater Household Dietary Diversity in Malawi: Findings from Nationally Representative Data. Food Policy 2014, 46, 1-12. [CrossRef]

26. Sibhatu, K.T.; Krishna, V.V.; Qaim, M. Production Diversity and Dietary Diversity in Smallholder Farm Households. Proc. Natl. Acad. Sci. USA 2015, 112, 10657-10662. [CrossRef] [PubMed]

27. Powell, B.; Thilsted, S.H.; Ickowitz, A.; Termote, C.; Sunderland, T.; Herforth, A. Improving Diets with Wild and Cultivated Biodiversity from Across the Landscape. Food Secur. 2015, 7, 535-554. [CrossRef]

28. Kirsten, J.; Townsend, R.; Gibson, C. Determining the Contribution of Agricultural Production to Household Nutritional Status in KwaZulu-Natal, South Africa. Dev. S. Afr. 1998, 15, 573-587. [CrossRef]

29. Ayenew, H.Y.; Biadgilign, S.; Schickramm, L.; Abate-Kassa, G.; Sauer, J. Production Diversification, Dietary Diversity and Consumption Seasonality: Panel Data Evidence from Nigeria. BMC Public Health 2018, 18, 988.

30. Carletto, C.; Corral, P.; Guelfi, A. Agricultural Commercialization and Nutrition Revisited: Empirical Evidence from Three African Countries. Food Policy 2017, 67, 106-118. [CrossRef] [PubMed]

31. Sekabira, H.; Nalunga, S. Farm Production Diversity: Is it Important for Dietary Diversity? Panel Data Evidence from Uganda. Sustainability 2020, 12, 1028. [CrossRef]

32. Lovo, S.; Veronesi, M. Crop Diversification and Child Health: Empirical Evidence from Tanzania. Ecol. Econ. 2019, 158, 168-179. [CrossRef]

33. Nandi, R.; Nedumaran, S.; Ravula, P. The Interplay between Food Market Access and Farm Household Dietary Diversity in Low and Middle Income Countries: A Systematic Review of Literature. Glob. Food Secur. 2021, 28, 100484. [CrossRef] 
34. Verger, E.O.; Gaillard, C.; Jones, A.D.; Remans, R.; Kennedy, G. Construction and Interpretation of Production and Market Metrics Used to Understand Relationships with Dietary Diversity of Rural Smallholder Farming Households. Agriculture 2021, 11, 749. [CrossRef]

35. Verger, E.O.; Ballard, T.J.; Dop, M.C.; Martin-Prevel, Y. Systematic Review of Use and Interpretation of Dietary Diversity Indicators in Nutrition-Sensitive Agriculture Literature. Glob. Food Secur. 2019, 20, 156-169. [CrossRef]

36. Brophy, T.; Branson, N.; Daniels, R.C.; Leibbrandt, M.; Mlatsheni, C.; Woolard, I. National Income Dynamics Study Panel User Manual; Release 2018; Version 1; Southern Africa Labour and Development Research Unit (SALDRU), University of Cape Town: Cape Town, South Africa, 2018.

37. Nwosu, C.O.; Woolard, I. The Impact of Health on Labour Force Participation in South Africa. S. Afr. J. Econ. 2017, 85, 481-490. [CrossRef]

38. Ruel, M.T. Operationalizing Dietary Diversity: A Review of Measurement Issues and Research Priorities. J. Nutr. 2003, 133, 3911S-3926S. [CrossRef]

39. Kennedy, G.T.; Dop, M. Guidelines for Measuring Household and Individual Dietary Diversity; Food and Agriculture Organization of the United Nations: Rome, Italy, 2011.

40. Swindale, A.; Bilinsky, P. Household Dietary Diversity Score (HDDS) for Measurement of Household Food Access: Indicator Guide (v.2); FHI 360/FANTA: Washington, DC, USA, 2006.

41. Arimond, M.; Wiesmann, D.; Becquey, E.; Carriquiry, A.; Daniels, M.C.; Deitchler, M.; Fanou-Fogny, N.; Joseph, M.L.; Kennedy, G.; Martin-Prevel, Y.; et al. Simple Food Group Diversity Indicators Predict Micronutrient Adequacy of Women's Diets in 5 Diverse, Resource-Poor Settings. J. Nutr. 2010, 140, 2059S-2069S. [CrossRef]

42. Ecker, O. Economic Transformation and Diets in Rural Ghana: Does Farm Production Diversity (Still) Matter? In The Third Global Food Symposium; University of Goettingen: Goettingen, Germany, 2017.

43. Bhagowalia, P.; Headey, D.; Kadiyal, S. Agriculture, Income, and Nutrition Linkages in India: Insights from a Nationally Representative Survey; Discussion Paper 01195; International Food Policy Research Institute (IFPRI): Washington, DC, USA, 2012.

44. Chinnadurai, M.; Karunakaran, K.R.; Chandrasekaran, M.; Balasubramanian, R.; Umanath, M. Examining Linkage between Dietary Pattern and Crop Diversification: An Evidence from Tamil Nadu. Agric. Econ. Res. Rev. 2016, 29, 149-160. [CrossRef]

45. Sibhatu, K.T.; Qaim, M. Farm Production Diversity and Dietary Quality: Linkages and Measurement Issues. Food Secur. 2018, 10, 47-59. [CrossRef]

46. Berti, P.R. Relationship between Production Diversity and Dietary Diversity Depends on how Number of Foods is Counted. Proc. Natl. Acad. Sci. USA 2015, 112, E5656. [CrossRef]

47. Gupta, S.; Sunder, N.; Pingali, P.L. Market Access, Production Diversity, and Diet Diversity: Evidence from India. Food Nutr. Bull. 2020, 41, 167-185. [CrossRef] [PubMed]

48. Cameron, A.C.; Trivedi, P.K. Microeconometrics: Methods and Applications; Cambridge University Press: New York, NY, USA, 2005.

49. Wooldridge, J.M. Econometric Analysis of Cross Section and Panel Data; MIT Press: Cambridge, MA, USA, 2002.

50. Faber, M.; Laubscher, R.; Laurie, S. Availability of, Access to and Consumption of Fruits and Vegetables in a Peri-Urban Area in KwaZulu-Natal, South Africa. Matern. Child Nutr. 2013, 9, 409-424. [CrossRef] [PubMed]

51. Faber, M.; Wenhold, F.A.; Laurie, S.M. Dietary Diversity and Vegetable and Fruit Consumption of Households in a Resource-Poor Peri-Urban South Africa Community Differ by Food Security Status. Ecol. Food Nutr. 2017, 56, 62-80. [CrossRef]

52. Okop, K.J.; Ndayi, K.; Tsolekile, L.; Sanders, D.; Puoane, T. Low Intake of Commonly Available Fruits and Vegetables in SocioEconomically Disadvantaged Communities of South Africa: Influence of Affordability and Sugary Drinks Intake. BMC Public Health 2019, 19, 940. [CrossRef]

53. Peltzer, K.; Phaswana-Mafuya, N. Fruit and Vegetable Intake and Associated Factors in Older Adults in South Africa. Glob. Health Action 2012, 5, 18668. [CrossRef] [PubMed]

54. Mehraban, N.; Ickowitz, A. Dietary Diversity of Rural Indonesian Households Declines over Time with Agricultural Production Diversity Even as Incomes Rise. Glob. Food Sec. 2021, 28, 100502. [CrossRef]

55. Bellon, M.; Ntandou-Bouzitou, G.; Caracciolo, F. On-farm diversity and market participation are positively associated with dietary diversity of rural mothers in Southern Benin, West Africa. PLoS ONE 2016, 11, e0162535. [CrossRef]

56. Jones, A.D. On-farm Crop Species Richness is Associated with Household Diet Diversity and Quality in Subsistence- and Market-Oriented Farming Households in Malawi. Nutr. J. 2016, 147, 86-96. [CrossRef] [PubMed]

57. Kissoly, L.D.; Karki, S.K.; Grote, U. Diversity in Farm Production and Household Diets: Comparing Evidence from Smallholders in Kenya and Tanzania. Front. Sustain. Food Syst. 2020, 4, 1-13. [CrossRef]

58. Kavitha, K.; Soumitra, P.; Padmaja, R. Understanding the Linkages between Crop Diversity and Household Dietary Diversity in The Semi-Arid Regions of India. Agric. Econ. Res. Rev. 2016, 29, 129-137. [CrossRef]

59. Romeo, A.; Meerman, J.; Demeke, M.; Scognamillo, A.; Asfaw, S. Linking Farm Diversification to Household Diet Diversification: Evidence from A Sample of Kenyan Ultra-Poor Farmers. Food Sec. 2016, 8, 1069-1085. [CrossRef]

60. Hirvonen, K.; Hoddinott, J. Agricultural Production and Children's Diets: Evidence from Rural Ethiopia. Agric. Econ. 2017, 48, 469-480. [CrossRef]

61. Usman, M.A.; Callo-Concha, D. Does Market Access Improve Dietary Diversity and Food Security? Evidence from Southwestern Ethiopian Smallholder Coffee Producers. Agric. Econ. 2021, 9, 18. [CrossRef] 
62. Mulenga, B.P.; Ngoma, H.; Nkonde, C. Produce to Eat or Sell: Panel Data Structural Equation Modeling of Market Participation and Food Dietary Diversity in Zambia. Food Policy 2021, 102, 102035. [CrossRef]

63. Murendo, C.; Nhau, B.; Mazvimavi, K.; Khanye, T.; Gwara, S. Nutrition Education, Farm Production Diversity, and Commercialization on Household and Individual Dietary Diversity in Zimbabwe. Food Nutr. Res. 2018, 62, 1276. [CrossRef]

64. Koppmair, S.; Kassie, M.; Qaim, M. Farm Production, Market Access and Dietary Diversity in Malawi. Public Health Nutr. 2017, 20, 325-335. [CrossRef] [PubMed]

65. Snapp, S.S.; Fisher, M. “Filling the Maize Basket" Supports Crop Diversity and Quality of Household Diet in Malawi. Food Sec. 2015, 7, 83-96. [CrossRef]

66. Cordero-Ahiman, O.V.; Santellano-Estrada, E.; Garrido, A. Dietary Diversity in Rural Households: The Case of Indigenous Communities in Sierra Tarahumara, Mexico. J. Food Nutr. Res. 2017, 5, 86-94.

67. Owusu, V.; Abdulai, A.; Abdul-Rahman, S. Non-farm Work and Food Security among Farm Households in Northern Ghana. Food Policy 2011, 36, 108-118. [CrossRef]

68. Reardon, T.; Berdegué, J.; Escobar, G. Rural Nonfarm Employment and Incomes in Latin America: Overview and Policy Implications. World Dev. 2001, 29, 395-409. [CrossRef]

69. Ruben, R.; Van den berg, M. Nonfarm Employment and Poverty Alleviation of Rural Farm Households in Honduras. World Dev. 2001, 29, 549-560. [CrossRef]

70. Banerjee, A.; Duflo, E. More than 1 billion People are Hungry in the World. Foreign Policy 2011, 186, 66-72.

71. Kissoly, L.; Faße, A.; Grote, U. Implications of Smallholder Farm Production Diversity for Household Food Consumption Diversity: Insights from Diverse Agro-Ecological and Market Access Contexts in Rural Tanzania. Horticulturae 2018, 4, 14. [CrossRef] 